\title{
The Empirical Study of Heterogeneity Firm's Internationalization Path Selection
}

\author{
Weizhong Jiang ${ }^{1} \& \mathrm{Xi} \mathrm{Xie}^{1}$ \\ ${ }^{1}$ Electronic Information Science and Technology of Electrical and Information School, Jinan University, Zhuhai, \\ Guangdong Province, China \\ Correspondence: Weizhong Jiang, Electronic information science and technology of Electrical and Information \\ School, Jinan University, Qianshan Road 206\#, Zhuhai City, Guangdong Province, Post No 519070, China. Tel: \\ 86-137-5005-6926. E-mail: 768242601@qq.com
}

Received: February 15, 2016

Accepted: February 27, 2016

Online Published: April 25, 2016

doi:10.5539/ijef.v8n5p95

URL: http://dx.doi.org/10.5539/ijef.v8n5p95

\begin{abstract}
This article explores the heterogeneity firm's internationalization path selection by The New Trade Theory. Considering the firm's heterogeneity, based on the listed automobile company, do empirical study on three internationalization path selection which are Export, Foreign Direct Investment(FDI) and Outsourcing, considered five micro factors including productivity, R\&D investment and other two macro factors, think of the scale of three internationalization path as explanatory variables, take the regression by weighted least square, principal components estimation, Panel Data Regression Model respectively and have a good goodness of fit. Combined with the national automobile firm's internationalization path selection, we build a comprehensive selection model of the firm's internationalization path selection, analyze the differential impact on the three path selection separately. Finally, we make suggestions to the national automobile firm's internationalization path selection and promote the model.
\end{abstract}

Keywords: weighted least square, principal components estimation, panel data, firm heterogeneity, internationalization path selection

\section{Introduction}

"Internationalization is an important issue for the firms who intend to expand their business and who want to be prosperous in today's competitive business environment (Amiri Aghdaie et al., 2012; Riasi \& Amiri Aghdaie, 2013). The process of internationalization has various prerequisites including but not limited to adopting effective marketing strategies (Riasi, 2015a; Riasi \& Pourmiri, 2015), implementing sustainable development guidelines (Riasi \& Pourmiri, 2016), redesigning the capital structure and considering new sources of financing (Riasi, 2015b)." As for internationalization path selection, there are so many theoretical and empirical studies. But traditional trade theory is often more concerned about the difference between the sectors by macro analysis ,ignoring the fact that endogenous factors have an impact on it. The New-new Trade Theory, which developed on the Traditional Trade Theory and The New Trade Theory, based on a hypothesis that there's a scale economy and imperfect competitive markets, explain the forms of international trade in the intra-industry specialization, put forward a new project—-heterogeneity firm's internationalization path selection.

The New-new Trade Theory was represented by The Heterogeneity Enterprise Model (Marc J. Melitz, 2003) and The Endogenous Boundary Model Of Enterprise (Antràs Pol, 2003), they analyzed the internationalization path selection and the global production organization of individual enterprise, analysis the original of international trade, profit and distribution, resource allocation and so on. There are 2 forms of firm's heterogeneity, the first is generated by the difference among firms' productivity in an industry, the second is generated by the difference of firm's organization forms. On this basis, Baldwin and Okubo (2006) considered enterprise migration, as their opinion, due to the scale economy, the transaction cost in economic power shall be lower (Antràs Pol, 2003). Therefore, enterprises in economic power would choose FDI, outsourcing and any other forms of internationalization to gain extra profit corresponding. Based on the heterogeneous firm trade model of Melitz, Helpman (2006) introduced FDI, so the model can support the theory of the Multi-National Corporation international decision (Andrew B. Bernard et al., 1995).

Nowadays, there are 3 internationalization path selections: Export, Foreign Direct Investment (FDI) and 
Outsourcing. Under the New-new Trade Theory, Bema and Jensen $(1995,1999)$ used the data of American firms by empirical study and show that in a sector, compared with non-exports, exports are advanced in scale, productivity, capital-intensity, the technology-intensive labor and price level (Andrew B. Bernard et al., 1995). Necke and Yeaple $(2007,2008)$ research the two ways of Foreign Direct Investment: Greenfield Investment and Cross-border Purchase by manufacturing cost (Volker Nocke et al., 2007). It shows that with higher productivity, firms would prefer choose Greenfield Investment, the others would choose Cross-border Purchasing (Volker Nocke et al., 2008). Antràs and Helpman (2004) summarized the four patterns for firms to integration or outsourcing (Antràs Pol et al., 2004): National Integration, National Outsourcing, Global Integration and Global Outsourcing. Chunding Li made optimized the structure of The New-new Trade Theory, use the global organization production selection to represent firms' selection of integration or outsourcing ( $\mathrm{Li}, 2010)$.

The automotive industry of China, as the Participants of Enterprise internationalization, There are exports, foreign investment, outsource in their international forms. On the part of export, from the 2000 years the trend has been growth for six consecutive years, but the growth of the automotive industry in China has been slowed. To the years 2013, the general export of the automotive industry has been slowed for 7.5\%. Exports overall situation is more and more austere. On the part of direct export, Investment is concentrated in the in developing countries of Africa, Latin America, they expand their overseas markets from sign the export, contracts or cooperation projects, some enterprises which have the advantage investing abroad one after another, but because of the late start, they have a big gap with the leading enterprises of the world. On the part of outsourcing, There are outsourcing in most of the car companies in China, The new energy vehicles in China are facing a problem , the problem is the missing of core technology of key components.

And for the choice of the international route study about the automotive industry, most of the researchers are exploratory research and qualitative research, and the quantitative research is less. Overall, Macro-study is more, and the Micro research is less. The Chinese scholars likes Bing Xiang Yan and Rong Ming Ren, they studied on the Macro analysis and Competitive advantage of Chinese automotive industry (Yan et al., 2007); Peng Fei Chou studied on the Macro analysis of the world's automotive industry and the sales strategy of Chinese automotive industry (Chou, 2002). But all of these, they have not enter the stage of using the New, new trade theory study. All about it, the field of Chinese automotive industry is blank, which is leaded by the New, new trade theory, there is much research on space. In the framework of The new trading system, The heterogeneity of enterprise, which decided Enterprise competitive behavior and Enterprise competitive advantage are endogenous, if we want to talk about the enterprise's international route, what important is to consider the actual situation of enterprise, then to study with macro environment.

This article used the data from listed automobile company, considered productivity, capital-intensive, specific investment, firm scale, R\&D investment, fixed cost, interstate transaction cost (Li et al., 2013), at the same time, added the macro factors like credit constraint in China, per capital GDP (Guo, 2013), contribute regression relation separately of the level of export, FDI and outsourcing and then building a comprehensive selection model of the firm's internationalization path selection. Finally, we make suggestions to the national automobile firm's internationalization path selection.

Due to the complicated data, this article adopt different regression model to analyzing. Because of the already mature of export and the enough data, we choose Panel Data Regression Model, analyzing the complex impact with more levels of economic variable on the level of export, it also can have a good deal with the metrology problems such as multicollinearity of data. As for FDI and Outsourcing, the constraint of data oblige us to use least-squares regression method with section data .In the regression, we considered the modified problem of typical assumption. As to outsourcing, considered about the heteroscedasticity of data, we used Weighted Least Square Method to regression. We also created principal components estimation to regression for serious multicollinearity of data in FDI. All three methods have good results on regression.

\section{Method}

\subsection{Determination of Indexes and Acquisition of Data}

\subsubsection{Independent Variable Index}

Considering whether to enter the international market, as well as through which channel to achieve the internationalization, series of evaluation factors need to be related. A firm has to measure not only profitability after internationalization but also the pressure from global market. Therefore, we take a number of micro factors of firms themselves and macro factors of international market into account, to establish an index system having influences on internationalization. 
First of all, beginning with the micro factors, here is a quantitative evaluation with competence the firms need when internationalization.

Firm Size $-x_{(\mathrm{j}, 1)}$ : Firm size is directly related to its influence on international market as well as its responsive ability to the uncertainty of the market (Yu, 2010). The larger a firm is, the larger influence it has on the international market, meanwhile, the better it dose in responding to uncertainty. However, if its size is larger, it is relatively difficult to adjust its strategy in response to the incident in the international market, i.e. it has a relatively smaller flexibility. Then, it is required that firm size should be taken into account when making international strategies.

Total Factor Productivity (TFP) $-x_{(j, 2)}$ : A firm's status in the international market is not only related of its firm size but its productivity (Liu, 2013). Here Solow Residual Value method is used to quantitatively evaluate the total factor productivity (TFP), as is shown in the following formula:

$$
x_{(j, 2)}=\ln \left(Q_{j} / L_{j}\right)-s \times \ln \left(K_{j} / L_{j}\right)
$$

Where $Q$ is called output of the firm, $L$ is called labor input, $K$ is called capital input.

$\mathrm{R} \& \mathrm{D}-x_{(j, 3)}: \mathrm{R} \& \mathrm{D}$ plays a crucial role for the long-term development of a firm, the more R\&D are inputted, the greater possibility, that competitive advantage will be improved, a firm has.

Capital Intensive $-x_{(j, 4)}$ : The index indirectly reflects a firm' productivity as well as relative cost. The larger capital intensive is likely corresponding with bigger proportion of capital in total cost, on the contrary, labor input has a bigger proportion.

Specific Investment- $x_{(j, 5)}$ : Specific investment contains fixed assets input and current assets input, a firm determines its internationalization path according to ratio of fixed and current assets inputs.

Fixed Cost $-x_{(j, 6)}$ and Transaction Cost $-x_{(j, 9)}$ : These two indexes directly reflect the absolute costs of internationalization. A firm, with FDI as its internationalization path, focuses more on the fixed cost of the strategy, a firm with export as its path concentrates more on its transaction cost. Here the fixed asset depreciation is used to quantify the fixed cost of a firm, while the part of transportation cost, which is related to exportation, is used to quantify the transaction cost.

Credit Constraint $-x_{(j, 7)}$ : Internationalization likely means a firm will be faced with greater uncertainty as well as fixed costs, then more capital support is needed, therefore, difficulty of gaining loans from banks is of great importance. To measure the credit constraint, the two aspects will be considered: the availability of loans and costs of loans. The availability of loans is directly related to whether enough capital can be borrowed, while the costs of loans reflect the willingness of a firm to continue to develop its overseas market with enough capital. Credit constrain index is determined based on shareholder equity as well as the domestic interest rate difference between savings and loan, as follow:

$$
x_{(\mathrm{j}, 7)}=\frac{E R_{j}}{i_{\text {loan }(\mathrm{j})}-i_{\text {deposit }(\mathrm{j})}}
$$

Where,

$x_{(\mathrm{j}, 7)} \quad$ credit constrain of a firm;

$E R_{j} \longrightarrow$ shareholder equity of a firm; 
$i_{\text {loan }(\mathrm{j})}-i_{\text {deposit }(\mathrm{j})} \longrightarrow$ domestic interest rate difference between savings and loan.

In addition, some factors of market environment where a firm develops should be taken into account, including various costs, risks and benefits when entering the market.

The Ratio of GDPs per Capita_ $x_{(j, 8)}$ : As for a firm with FDI or outsourcing selected, on one hand, from the aspects of costs, countries with lower GDP per capita are preferred. On the other hand, from the aspects of technology, countries with higher GDP per capita are preferred. Besides, that exporting to the ones with higher GDP per capita likely brings more profits.

$$
x_{(j, 8)}=\frac{G D P^{p e r}(\mathrm{j}, \mathrm{m})}{G D P^{\text {per }}}
$$

Where,

$G D P_{(j, \mathrm{~m})}^{\text {per }}$ GDP per capita of the number $m$ relative country of the number $j$ firm;

$G D P_{d}^{p e r}$ domestic GDP per capita.

\subsubsection{Dependent Variable Indexes}

To evaluate the level of internationalization, we quantify the scales of firms developing corresponding international paths. As for export, it can be measured by operating revenue related to a certain firm's exporting, which is used as exporting dependent variable $-\operatorname{Exp}_{j}$. As for FDI, it can be measured by the total registered capital of overseas joint ventures as well as overseas subsidiaries of a certain firm, which is used as FDI dependent variable- $-F D I_{j}$. As for outsourcing, it can be measured by the total amount of outsourcing projects of a certain firm, which is used as outsourcing dependent variable- $-O u t_{j}$.

\subsubsection{Acquisition and Normalization of Data}

Here all listed companies of automobile industry in China are the original sample, according to their 2010-2013 annual financial reports (available in websites of Shanghai Stock Exchange and Shenzhen Stock Exchange in China), where the ones involved in exports or international outsourcing or FDI respectively are selected, 46 firms in total, such as FOTON, Yutong Bus, Cosic, and so on. What are available in those annual financial reports are data of 7 micro variables, including productivity, capital intensive, specific investment firm size, $\mathrm{R} \& \mathrm{D}$, fixed costs, international transaction costs, as well as data of 3 dependent variables, including scales of export, outsourcing and FDI. While GDPs per capita of related countries are available in the website of IMF, interest rates of savings and loan in China in certain years are available in the website of WBG, according to which the data of 2 macro variables are available. Then, with the data of these micro and macro factors, all data of the micro financial indexes, credit constraint as well as the ratios of GDPs per capita are available.

According to the data sufficiency respectively of 3 dependent variables - the data of export is relatively abundant, while the data of FDI and outsourcing are relatively less, then comes the final data range: the data of 38 selected automobile firms with the period between 2010 and 2013 (4 years in total) are used to construct the panel data of regression analysis of export. While as for the regression analysis of FDI, the total scale of 4 years of 25 selected automobile firms are used for corresponding dependent variable, what is different is that this is a cross-section regression. Similarly, as for the international outsourcing, what used for corresponding regression is cross-section data from 23 selected firms.

According to the annual financial reports, it is not difficult to be analyzed that there is large difference between dimensions of various variables, which has a great effect on whether a certain variable should be eliminated during a regression, which requires the data is dimensionless before regression (Bao et al., 2010). Here the following normalization method is applied, taking the firm size $x_{(\mathrm{j}, 1)}$ for example:

$$
x_{(, 1)}=\frac{\hat{x}_{(j, 1)}-\min _{j}\left\{\hat{x}_{(1)}\right\}}{\max _{j}\left\{\hat{x}_{(1)}\right\}-\min _{j}\left\{\hat{x}_{(1)}\right\}}
$$

Where,

$x_{6,1,1}$ - the dimensionless firm size of the number ${ }_{j}$ firm related to the number $m$ international path;

$\hat{x}_{(, 1)}$ - the original firm size of the number $j$ firm related to the number $m$ international path; 
$\min _{j}\left\{\hat{x}_{(1)}\right\}$ - the minimum of all firm sizes of the number $m$ international path;

$\max _{j}\left\{\hat{x}_{(1)}\right\}$ - the maximum of all firm sizes of the number $m$ international path;

After normalization as above, all variables can be used for the following empirical researches.

\subsection{Revised Regression Model of Outsourcing}

Classic linear regression model can obtain unbiased and efficient estimation in several basic assumptions. However, practice problems in econometrics could merely meet all assumptions. Therefore, we need to test these hypotheses and dispose some of hypothesis which are insatiability. Hypotheses we need to test consist of heteroscedasticity, multicollinearity, and randomized explanatory variable question (Li et al., 2004).

We apply $O L S$ to classic regression for outsourcing- automotive company, and the formula is as followed:

$$
\begin{aligned}
\text { Out }_{j}= & -0.09-0.58 x_{(\mathrm{j}, 1)}-0.28 x_{(\mathrm{j}, 2)}+0.41 x_{(\mathrm{j}, 3)}-0.73 x_{(\mathrm{j}, 4)} \\
& +0.87 x_{(\mathrm{j}, 5)}+0.24 x_{(\mathrm{j}, 6)}-0.49 x_{(\mathrm{j}, 7)}+1.03 x_{(\mathrm{j}, 8)}
\end{aligned}
$$

In this formula, coefficient of determination is $R_{\text {out }-0}^{2}=0.69$, p-value of F-test is 0.01 , but p-values of t-test for all coefficients do not have significance, so efficiency in this formula is not good, the result of test is in Table 1.

Table 1. Estimation and t-test in $O L S$ Regression Model

\begin{tabular}{ccc}
\hline Parameter & Estimation & p-value \\
\hline constant term & -0.09 & 0.75 \\
firm size & -0.28 & 0.39 \\
productivity & -0.73 & 0.09 \\
R\&D & 0.87 & 0.05 \\
capital intensive & 0.41 & 0.09 \\
specific investment & -0.58 & 0.05 \\
fixed cost & 0.24 & 0.51 \\
credit constraint & 1.03 & $0.03^{*}$ \\
GDP per capita & -0.49 & $0.03^{*}$ \\
\hline
\end{tabular}

Table 1 shows that the efficiency of $O L S$ Regression Model is bad, that means sample data do not meet the condition of $O L S$, so it requires us to test the hypotheses of the sample data according to the condition of $O L S$, to judge if the sample data could meet the basic assumption of $O L S$.

\subsubsection{Test and Disposal of Heteroscedasticity}

One of basic hypotheses in classic regression equation is homoscedasticity model, a possibility of biased model is that there is heteroscedasticity in the model. Heteroscedasticity means variance of stochastic error in regression model is not a constant for different firms. However, there is a hypothesis-homoscedasticity in classic model, in order to make the model more accurate, we shall test if this model is heteroscedasticity.

We judge if there is heteroscedasticity in the model using graphic method, as an example, we shall analyze test result of fixed cost and GDP per capita, as show in Figure 1 and Figure 2.

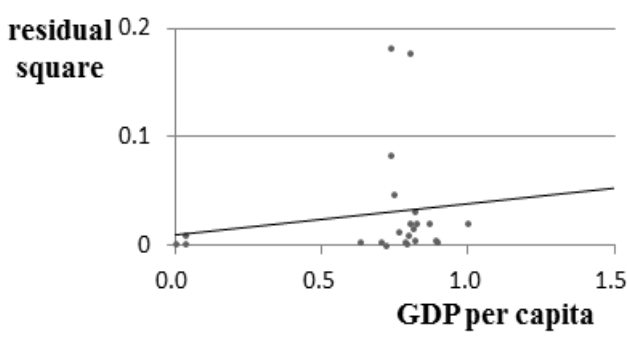

Figure 1. GDP per capita \& $e_{j}^{2}$ 


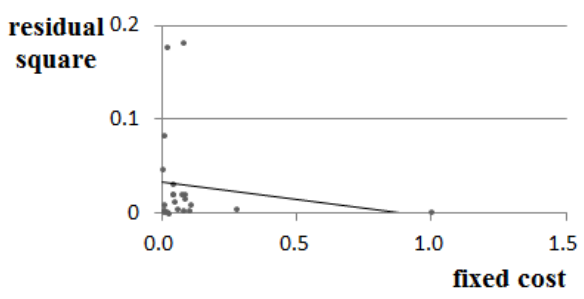

Figure 2. Fixed cost \& $e_{j}^{2}$

In the regression model meeting homoscedasticity assumption, the slope of trend line for residual squares is 0 . However, Figure 1 and Figure 2 suggests that slope are not equal to 0, their distribution exhibit an increasing or decreasing trend, that means this model do not meet the assumption of homoscedasticity, that is to say, there is heteroscedasticity in sample data, so the model need to be disposed.

This study adopt weighted least square method (WLS) to dispose heteroscedasticity, in order structure a new homoscedasticity model, then we could use $O L S$ to estimate parameters. On a separate note, the key of weighted least square method is to look for a function linking variance of stochastic error $(\mu)$ to independent variables, which is used to eliminate correlation among data. Thus, each parameter should be multiplied by a weight $\left(1 \frac{1}{)}\right)$, and the outsourcing model is as followed:

$\overline{|e|}$

$$
\left(\begin{array}{c}
\text { Out }_{1} \\
\vdots \\
\text { Out }_{n}
\end{array}\right) /\left(e_{1} \cdots e_{n}\right)=\left(\begin{array}{c}
\beta_{0} \\
\vdots \\
\beta_{8}
\end{array}\right)\left(\begin{array}{ccc}
1 & x_{(1,1)} \cdots & x_{(1,8)} \\
\vdots & \ddots & \vdots \\
1 & x_{(\mathrm{n}, 1)} \cdots & x_{(\mathrm{n}, 8)}
\end{array}\right) /\left(e_{1} \cdots e_{j}\right)+\left(\begin{array}{c}
\mu_{1} \\
\vdots \\
\mu_{n}
\end{array}\right) /\left(e_{1} \cdots e_{n}\right)
$$

Where,

$\left(\text { Out }_{1} \cdots \text { Out }_{n}\right)^{\prime}-$ The level of outsourcing for $n$ firms;

$\left(e_{1} \cdots e_{n}\right)-$ Residual errors from classic regression model;

$\left(\beta_{0} \cdots \beta_{8}\right)^{\prime}-$ Coefficient of regression model;

$x_{(\mathrm{j}, \mathrm{k})}$ - The $k$-th independent variable in the $j$-th firm;

$\left(\mu_{1} \cdots \mu_{n}\right)^{\prime}$-Error term from classic regression model.

\subsubsection{Test of Multicollinearity and Randomized Explanatory Variable Question}

After attaining modified heteroscedasticity model, we still need to test the problems of multicollinearity and randomized explanatory variable question.

Multicollinearity could be judged by t-test of regression coefficient, when the p-value is less than 0.01 , null hypothesis is rejected, which means the coefficient is valuable. When the p-values of all coefficients are less than 0.05 , then the model do not have multicollinearity problem, the result of test is in Table 2 . 
Table 2. T-test in modified heteroscedasticity model

\begin{tabular}{ccl}
\hline Parameter & Estimation & $\mathrm{p}$-value \\
\hline constant term & -0.0945 & 0.4577 \\
firm size & -0.6425 & $0.0001 * * *$ \\
productivity & -0.3606 & $0.0017 * * *$ \\
R\&D & 0.4195 & $0.0007 * * *$ \\
capital intensive & -0.7455 & $0.0004 * * *$ \\
specific investment & 0.9096 & $0.0009 * * *$ \\
fixed cost & 0.3003 & $0.0572 *$ \\
credit constraint & -0.4950 & $0.0004 * * *$ \\
GDP per capita & 1.0617 & $0.0007 * * *$ \\
\hline
\end{tabular}

Table 2 Shows there is not multicollinearity problem among independent variables, $t$-test of each coefficient is significant, which means the null hypothesis is rejected.

For the randomized explanatory variable question, it could be judge by covariance of independent variables and randomized variable matrix, the result is as followed:

$$
\begin{aligned}
& \operatorname{Cov}(X, \mu) \\
& =(3 E-12, \quad 5 E-12, \quad 5 E-12, \quad 3 E-12, \quad 2 E-12, \quad 2 E-12, \quad 6 E-12, \quad 8 E-12) \\
& \approx O \\
& \left\{\begin{array}{l}
X=\left(\begin{array}{ccc}
x_{(1,1)} & \cdots & x_{(1,8)} \\
\vdots & \ddots & \vdots \\
x_{(\mathrm{n}, 1)} & \cdots & x_{(\mathrm{n}, 8)}
\end{array}\right)^{\prime} \\
\mu=\left(\hat{\mu}_{1} \cdots \hat{\mu}_{n}\right)^{\prime}
\end{array}\right.
\end{aligned}
$$

The result suggests the covariance matrix of independent variables and randomized variable matrix is 0 . That means there is no correlation between independent variables and randomized variable, that is to say there is no randomized explanatory variable question in this model.

\subsection{Regression Model of FDI}

Similarly, after the normalized processing of the original data of FDI, We apply $O L S$ to classic regression for FDI company, and the formula is as followed (the p-value of the estimation of coefficient by t-test is annotated below the estimation of coefficient):

$$
\begin{aligned}
& F D I_{j}=1.26-0.62 x_{(j, 1)}-1.12 x_{(j, 2)}+0.75 x_{(j, 3)}-1.12 x_{(j, 4)} \\
& \begin{array}{lllll}
(4.1 \%) & (58.8 \%) & (4.8 \%) & (48.0 \%) & (4.6 \%)
\end{array} \\
& -0.13 x_{(j, 5)}+0.23 x_{(j, 6)}+0.21 x_{(j, 7)}-0.19 x_{(j, 8)} \\
& \begin{array}{llll}
(58.0 \%) & (36.5 \%) & (20.4 \%) & (30.8 \%)
\end{array}
\end{aligned}
$$

Where $F D I_{j}$ represents the level of foreign direct investment of the $j$-th company.

In this formula, coefficient of determination is $R_{F D I-0}^{2}=0.68$, p-value of F-test is 0.0067 . Obviously, its effect of regression is poor and p-values of t-test for many coefficients bigger than 0.05 , that is to say, we can't refuse coefficient is not equal to zero significantly. The reason why the effect of regression is poor will be analyzed below.

\subsubsection{The Detection of Stochastic Explanatory Variables Problem}

It assumes that the explanatory variables and the corresponding stochastic disturbance are independent of each other in the classical regression. It means the covariance of them is 0 . Otherwise, the stochastic explanatory variables problem is exist. 


$$
\begin{aligned}
& \operatorname{Cov}\left(x_{j k}, \mu_{j}\right) \\
& =(9 E-18, \quad-7 E-19, \quad 7 E-18, \quad-3 E-18, \quad 6 E-18, \quad 2 E-17, \quad-2 E-18, \quad 4 E-18)^{\prime} \\
& \approx O
\end{aligned}
$$

Where $9 E-18$ is equal to $9 \times 10^{-18}$.

Therefore, we can draw a conclusion that the stochastic explanatory variables problem is not exist.

\subsubsection{The Detection of Multicollinearity Problem}

According to the result of p-value of F-test and the p-values of each estimator of coefficient by t-test, we can estimate the multicollinearity problem may exist. And multicollinearity problem is tested by the method of coefficient of determination in the study. It solve the regression equation with each explanatory variables $\left(x_{j}\right)$ and the rest of the explanatory variables $\left(x_{j_{2}}, j_{2} \neq j_{1}\right)$ by method of $O L S$. And calculate the corresponding coefficient of determination and the F statistics. Then we could judge whether the multicollinearity problem exists.

Assuming $x_{j}$ as dependent variable and $x_{j_{2}}\left(j_{2} \neq j\right)$ as independent variables, we can get the coefficient of determination $\left(R_{j}^{2}\right)$ and the F statistics $\left(F_{j}\right)$ regression analysis.

Table 3. The test results for determining coefficient

\begin{tabular}{ccccccccc}
\hline$i$ & 1 & 2 & 3 & 4 & 5 & 6 & 7 & 8 \\
\hline$R_{j}^{2}$ & 0.97 & 0.88 & 0.98 & 0.86 & 0.20 & 0.68 & 0.26 & 0.36 \\
$F_{j}$ & 90.04 & 18.14 & 77.52 & 14.54 & 0.62 & 5.12 & 0.87 & 1.36 \\
\hline
\end{tabular}

By Table 3, it's not hard to see, all coefficient of determination $\left(R_{j}^{2}\right)$ and F statistics $\left(F_{j}\right)$ are very big when $j=1,2,3,4,6$. In other words, the $x_{j}$ and other explanatory variables have the obvious collinearity. As to it, the study will use the principal component estimate method to overcome the multicollinearity.

\subsubsection{The Principal Component Estimate Method}

Principal component estimate is one of the linear biased estimation of regression coefficient. It can be used to overcome of instability by the multicollinearity problem of the least-squares (LS) estimate.

It depends that variables of the original regression are transformed into another set of variables as new independent variables. Then using least square method to select principal component estimate parameter model, and then will transform the original model and parameter estimates. Using least square method to make the principal components model parameters estimated, and finally transforms it into the original model parameter.

Processing, $P C_{i}(i=1,2, \ldots 8)$ represent the principal components. Their characteristic values are $\eta_{i}$. They obey the following formula:

$$
P C_{i}=X \eta_{i},(i=1,2, \ldots 8)
$$

\subsection{Based on Export Panel Data Regression Model}

For the analysis of the export in the automotive industry, from the point of cross-section data, different enterprises show heterogeneity at the same time. If ignore this feature between enterprises will lead to biased result. From the point of time series data, changes in different periods of financial data, export levels also have corresponding change. But the classical regression model only researches the difference between different enterprises and ignores the change over time. So that the study uses the regression modeling based on export panel data. Panel data carry more dynamic information than cross-section data. It can be used to study the different period of time of each enterprise and the heterogeneity of each enterprise. 


\subsubsection{Unit Root Test}

Classical regression model is built on the basis of stable data variables, for non-stationary variables, you cannot use classical models, otherwise, there would be a Spurious Regression and other issues. Therefore, you first need to be tested stability variables that unit root test (Li et al., 2004).

According to the panel data unit root test theories, respectively, testing the amount of each company's exports $\operatorname{Exp}_{j}$, firm size $x_{(\mathrm{j}, 1)}$, total factor productivity $x_{(j, 2)}, \mathrm{R} \& \mathrm{D}$ investment $\operatorname{In} x_{(j, 3)}$, capital intensity $x_{(j, 4)}$, fixed costs $x_{(j, 6)}$, transaction costs $x_{(j, 9)}$, credit constraints $x_{(j, 7)}$, and GDP per capita ratio $x_{(j, 8)}$ by unit root test. For panel data, ADF-Fisher and PP-Fisher test results for the better, because these two methods can test different cross-sectional panel data by unit root test. The ultimate combine test results for each test section, reconstruct statistics, and judge whether it contains unit root in the entire panel data. So, we use LLC tests which have the same unit root, ADF-Fisher tests and PP-Fisher tests which have different unit roots, according to the test results to determine whether the variables between each other have the panel unit root (Zhang, 2012).

Table 6. Unit root test results dependent variables and independent variables

\begin{tabular}{cccc}
\hline variables & LLC & ADF-Fisher & PP-Fisher \\
\hline $\operatorname{Exp}_{j}$ & $0.0000 * *$ & $0.0000 * *$ & $0.0000 * *$ \\
$x_{1}$ & $0.0000 * *$ & $0.0000 * *$ & $0.0000 * *$ \\
$x_{2}$ & $0.0000 * *$ & $0.0006 * *$ & $0.0000 * *$ \\
$\operatorname{In} x_{3}$ & $0.0000 * *$ & $0.0003 * *$ & $0.0000 * *$ \\
$x_{4}$ & $0.0000 * *$ & $0.0687 *$ & $0.0014 * *$ \\
$x_{6}$ & $0.0000 * *$ & $0.0002 * *$ & $0.0000 * *$ \\
$x_{7}$ & $0.0000 * *$ & $0.0452 * *$ & $0.0009 * *$ \\
$x_{8}$ & $0.0000 * *$ & $0.0000 * *$ & $0.0000 * *$ \\
$x_{9}$ & $0.0000 * *$ & $0.0025 * *$ & $0.0001 * *$ \\
\hline
\end{tabular}

Note. $* *$ and $*$ mean passing the significance tests in the $5 \%$ and $10 \%$ significance level.

Table 6 shows that, at the 5\% significance level, $\operatorname{Exp}_{j}, x_{1}, x_{2}, \operatorname{In} x_{3}, x_{6}, x_{7}, x_{8}, x_{9}$ reject unit root exists between variables, reject non-stationary panel data. Therefore, the classical regression model can be directly used for data regression.

\subsubsection{Hausman Test}

In order for the panel data regression model fixed effects model and random effects models were compared, we need to test random effects by Hausman test (Zhang, 2012). Test statistic is:

$$
W=\left(\hat{b_{\mathrm{CV}}}-\hat{b_{\mathrm{GLS}}}\right)\left[\operatorname{var}\left(\hat{b_{\mathrm{CV}}}\right)-\operatorname{var}\left(\hat{b_{\mathrm{GLS}}}\right)\right]^{-1}\left(\hat{b_{\mathrm{CV}}}-\hat{b_{\mathrm{GLS}}}\right)
$$

Where $k$ is number of explanatory variables, $\hat{b_{\mathrm{CV}}}$ is parameter estimation of fixed effects model, $\hat{b_{\mathrm{GLS}}}$ is parameter estimation of a random effects model. In the case of the establishment of the null hypothesis, $W$ should be subject to $k$ degrees of freedom for the chi-square distribution, namely: $W=X^{2}(k)$

(1) The null hypothesis is: the panel data model is the random effects model; 
(2) The alternative hypothesis is: the panel data model is the fixed effects model.

Table 7. Eviews 8 software to get the Hausman test results

\begin{tabular}{cccc}
\hline Test Summary & Chi-Sq. Statistic & Chi-Sq. d.f. & Prob. \\
\hline Cross-section random & 39.9188 & 8 & 0.0000 \\
\hline
\end{tabular}

The data in Table 7 shows, the overall value of the Hausman statistic is $W=39.92>X_{0.05}^{2}(8)=15.51$, corresponding to the overall probability is 0.0000 , showing that the test results reject the null hypothesis of a random effects model, namely that there is a fixed effects model. So it should establish a fixed effects model.

\subsubsection{Construction of the Panel Data Model}

Panel data is to take on more than one section each time series, while selecting sample data through sample observations on these cross-sections, which is a cross-sectional and time-series data fusion together data sets. Compared with the time-series and cross-sectional analysis, panel data indicate the presence of heterogeneity between individuals, ignoring the heterogeneity of the survey results will lead to biasness; and, panel data can carry more information than the time sequence, allowing a big difference of data, the degrees of freedom and Efficiency bigger than time-series data, eliminating the multicollinearity of time series. Therefore, building panel data model with the export scale and respective variables.

Hausman test obtained by various companies' exports and their variables to meet the fixed effects regression model variables, usually in the form of individual fixed effects model are as follows:

$$
y_{j t}=\alpha_{j}+x_{j t} \beta_{j}+u_{j t} \quad j=1,2, \ldots, N ; t=1,2, \ldots, T
$$

According to whether the constant term and the coefficient vector is constant, and the actual meaning, the paper considers two types of models, the fixed coefficient models and the variable intercept model (Zhang, 2012), assuming that the two models are as follows:

Assumption 1: $\alpha_{i}=\alpha_{j}, \beta_{i}=\beta_{j}, i \neq j$, that is not change of the intercept and slope, ie fixed coefficient model:

$$
y_{j t}=\alpha+x_{j t} \beta_{j}+u_{j t}
$$

Assumption 2: $\alpha_{i} \neq \alpha_{j}, \beta_{i}=\beta_{j}, i \neq j$, that is not change of the slope and change of the intercept, i.e. variable intercept model:

$$
y_{j t}=\alpha_{j}+x_{j t} \beta+u_{j t}
$$

\section{Results}

\subsection{The Results of Outsourcing Modification Model}

After disposal of hypotheses, then we shall evaluate the fitting effect of the model. P-value of F-test in modified regression model of outsourcing is $8.22 \times 10^{-10}$, coefficient of determination is $R_{\text {out }-1}^{2}=0.98$, that means the model has a good fitting effect, it is much better than classic regression model we built. Thus, we determine this modified model as our outsourcing selection model:

$$
\begin{array}{r}
\text { Out }^{*}{ }_{j}=-0.09-0.64 x_{(\mathrm{j}, 1)}-0.36 x_{\mathrm{j}, 2)}+0.42 x_{(\mathrm{j}, 3)}-0.75 x_{\mathrm{j}, 4)} \\
+0.91 x_{(\mathrm{j}, 5)}+0.30 x_{(\mathrm{j}, 6)}-0.50 x_{(\mathrm{j}, 7)}+1.06 x_{(\mathrm{j}, 8)}
\end{array}
$$

In our outsourcing selection model, coefficient of several independent variables such as firm size, productivity, capital intensive and credit constraint is negative value, that illustrates there is a negative correlation between these variables and the level of outsourcing firms. When the firm has a large scale, high productivity and high capital intensive, willingness of outsourcing shall be weaken, that accounts for firms in automobile industry are more willing to technology outsourcing, when corporate productivity goes higher, the firm is more willing to technology outsourcing. In addition, the tighter the corporate credit constraint is, the poor of possibility of 
outsourcing, because outsourcing needs more prophase cost and faces more risk compared to domestic operation. Nevertheless, there is a positive relationship between the level of outsourcing firms and some independent variables such as specific investment, fixed cost and GDP per capita, that explains when fixed cost in automobile manufacturing, firm is more willing to contract issuing for its part of production chain, at the same time, relative GDP per capita also identifies automobile firms are willing to deem developed countries as a better outsource.

\subsection{The Results of FDI Regression Model}

Through Matlab programming, we can get the characteristic values of the principal component and its degree for the interpretation of the total variance. Shown in the following Table 4.

Table 4. The explanation of the total variance for principal components

\begin{tabular}{cccc}
\hline principal components & characteristic values & contribution ratio $(\%)$ & Cumulative $(\%)$ \\
\hline$P C_{1}$ & 2.95 & 36.84 & 36.84 \\
$P C_{2}$ & 1.87 & 23.42 & 60.26 \\
$P C_{3}$ & 1.26 & 15.70 & 75.96 \\
$P C_{4}$ & 1.00 & 12.50 & 88.46 \\
$P C_{5}$ & 0.56 & 6.95 & 95.41 \\
$P C_{6}$ & 0.29 & 3.63 & 99.04 \\
$P C_{7}$ & 0.06 & 0.78 & 99.82 \\
$P C_{8}$ & 0.01 & 0.18 & 100.00 \\
\hline
\end{tabular}

In view of the cumulative contribution rate of not less than $80 \%$, and the number of principal component keep at least four. Further, we can get the feature vector of each principal component which shown in table 5:

Table 5. Characteristics value of principal components

\begin{tabular}{|c|c|c|c|c|c|c|c|c|}
\hline$P C_{i}$ & $P C_{1}$ & $P C_{2}$ & $P C_{3}$ & $P C_{4}$ & $P C_{5}$ & $P C_{6}$ & $P C_{7}$ & $P C_{8}$ \\
\hline$x_{1}$ & -0.37 & -0.49 & -0.27 & -0.15 & 0.12 & 0.10 & 0.71 & -0.02 \\
\hline$x_{2}$ & 0.09 & 0.65 & 0.29 & -0.03 & -0.24 & 0.20 & 0.61 & -0.08 \\
\hline$x_{3}$ & -0.01 & -0.17 & 0.76 & 0.07 & 0.62 & 0.01 & 0.07 & 0.01 \\
\hline$x_{4}$ & 0.55 & -0.17 & -0.04 & -0.04 & 0.02 & -0.43 & 0.18 & -0.67 \\
\hline$x_{5}$ & 0.56 & -0.16 & -0.01 & 0.02 & -0.06 & -0.27 & 0.25 & 0.73 \\
\hline$x_{6}$ & 0.49 & -0.22 & -0.07 & -0.08 & 0.04 & 0.83 & -0.07 & -0.09 \\
\hline$x_{7}$ & -0.06 & -0.30 & 0.20 & 0.81 & -0.44 & 0.06 & 0.07 & -0.07 \\
\hline$x_{8}$ & -0.09 & -0.33 & 0.47 & -0.55 & -0.59 & -0.03 & -0.11 & -0.01 \\
\hline
\end{tabular}

According to Table 5, take the first component as an example, the formula of the first component is as follows:

$$
P C_{1}=-0.37 x_{1}+0.09 x_{2}-0.01 x_{3}+0.55 x_{4}+0.56 x_{5}+0.49 x_{6}-0.06 x_{7}-0.09 x_{8}
$$

Such as mentioned above at least keep four principal components regression with the dependent variable, we first use four principal components regression with the dependent variable $F D I_{j}$. Then we use more principal components regression with the dependent variable $F D I_{j}$ until all principal components are used. Eventually, we find that the regression effect is best when electes 7 principal components. Compared with the coefficient of determination $R_{F D I-1}^{2}=0.78$ and the initial regression $R_{F D I-0}^{2}=0.68$, the regression results have improved. Finally, we combine the formula of the component and the regression equation to solve the original expression with the 
initial explanatory variables. The reslut is as follows:

$$
\begin{aligned}
& F D I_{j}^{*}=1.32+0.01 x_{(j, 1)}-1.14 x_{(j, 2)}+0.17 x_{(j, 3)}-1.19 x_{(j, 4)} \\
& -0.12 x_{(j, 5)}+0.17 x_{(j, 6)}+0.20 x_{(j, 7)}-0.24 x_{(j, 8)}
\end{aligned}
$$

In the formula 11, enterprise scale, research and development investment share, fixed costs and credit constraints are related to the level of FDI. Productivity, capital intensity, specific investment and rival countries relative to GDP per capita is negatively related to the level of FDI. Therefore, we can draw a conclusion that the more abundant of overall financial strength, attention of technology research and development, more large fixed costs, the more willing to choose foreign direct investment. There is no doubt that FDI is suitable for big company business strategy.

\subsection{The Results of Based on Export Panel Data Regression Model}

By Eviews8 software, two kinds of model is solved and compared. And according to heteroskedasticity and variable coefficient T-test for model improvement, we get the final panel data model.

Table 8. Comparison of goodness of fit in different models

\begin{tabular}{ccccc}
\hline & $\begin{array}{c}\text { fixed coefficient } \\
\text { model }\end{array}$ & $\begin{array}{c}\text { variable intercept } \\
\text { model }\end{array}$ & $\begin{array}{c}\text { Heteroskedasticity } \\
\text { correction }\end{array}$ & $\begin{array}{c}\text { Validity } \\
\text { coefficients }\end{array}$ \\
\hline$R^{2}$ & 0.2322 & 0.8355 & 0.9630 & 0.9636 \\
The standard error & 0.1533 & 0.0824 & 0.0733 & 0.0734 \\
P value (F- test) & 0.0000 & 0.0000 & 0.0000 & 0.0000 \\
\hline
\end{tabular}

Table 8 Data shows that the goodness of fit of variable intercept model $R_{\text {eppll }}^{2}=0.84>0.23$, illustrate the goodness of fit of variable intercept model significantly better than fixed coefficient model, which can be seen, there are obvious differences in the company's intercept.

Because the stochastic error presence sectional heteroscedasticity, we need for heteroscedasticity correction, using estimation method of cross-section weighted GLS to solve the model. In heteroskedasticity correction model, the corresponding coefficient of capital intensity $x_{(j, 4)}$ (independent variable), has $\mathrm{P}$ value of $0.38>0.05$ in $\mathrm{T}$ test, which cannot reject the null hypothesis which the coefficient is zero. Therefore, the removal of the independent variable capital intensity $\boldsymbol{X}_{(j, 4)}$, we get the final variable intercept panel model in heteroskedasticity correction. Results by Eviews 8 software to solve the following.

Table 9. Results of variable intercept panel model in heteroskedasticity correction test

\begin{tabular}{cc}
\hline$R^{2}$ & 0.9636 \\
\hline$\tilde{R}^{2}$ & 0.9486 \\
standard deviation & 0.0734 \\
F & 64.370 \\
P value (F- test) & 0.0000 \\
\hline
\end{tabular}

Table 10. Independent variable corresponding coefficients and their T-test

\begin{tabular}{ccccc}
\hline variables & estimator & standard deviation & t-value & P value \\
\hline$x_{1}$ & -0.171 & 0.081 & -2.117 & 0.037 \\
$x_{2}$ & -0.167 & 0.072 & -2.326 & 0.022 \\
$\ln x_{3}$ & 0.015 & 0.005 & 2.751 & 0.007 \\
$x_{4}$ & 0.176 & 0.087 & 2.034 & 0.045 \\
$x_{7}$ & 0.120 & 0.029 & 4.087 & 0.000 \\
$x_{8}$ & 0.416 & 0.097 & 4.271 & 0.000 \\
$x_{9}$ & -0.178 & 0.078 & -2.289 & 0.024 \\
\hline
\end{tabular}

From Table 9, the panel regression models exist, and fit better. From the data in Table 10, the independent 
variable coefficients have T-tests that the $\mathrm{P}$ values are all less than 0.05 , rejecting the null hypothesis that coefficients equal to zero, i.e. the coefficient of each variable is significantly different from zero, i.e. the regression coefficient is valid.

Therefore, the final result of variable intercept panel model in heteroscedasticity correction is estimated as follows:

$$
\begin{aligned}
\operatorname{Exp}_{j}{ }_{j} & =0.042+\alpha_{j}^{*}-0.171 x_{(j, 1)}-0.167 x_{(j, 2)}+0.015 x_{(j, 3)}+0.176 x_{(j, 6)} \\
& +0.120 x_{(j, 7)}+0.416 x_{(j, 8)}-0.178 x_{(j, 9)}
\end{aligned}
$$

Which specific values of fixed effects $\alpha_{j}^{*}$ Table 11 .

Table 11. Different companies' sectional fixed effects

\begin{tabular}{lclclc}
\hline NO & fixed effects $\alpha_{j}^{*}$ & NO & fixed effects $\alpha_{j}^{*}$ & NO & fixed effects $\alpha_{j}^{*}$ \\
\hline COM1--C & 0.127 & COM14--C & 0.116 & COM27--C & 0.010 \\
COM2--C & -0.038 & COM15--C & 0.301 & COM28--C & -0.135 \\
COM3--C & 0.297 & COM16--C & -0.087 & COM29--C & 0.295 \\
COM4--C & 0.046 & COM17--C & -0.321 & COM30--C & -0.070 \\
COM5--C & -0.169 & COM18--C & 0.201 & COM31--C & -0.365 \\
COM6--C & -0.020 & COM19--C & 0.110 & COM32--C & -0.197 \\
COM7--C & 0.143 & COM20--C & 0.181 & COM33--C & 0.016 \\
COM8--C & 0.268 & COM21--C & -0.181 & COM34--C & -0.295 \\
COM9--C & 0.020 & COM22--C & 0.056 & COM35--C & 0.371 \\
COM10--C & -0.120 & COM23--C & 0.016 & COM36--C & -0.189 \\
COM11--C & -0.003 & COM24--C & -0.080 & COM37--C & -0.142 \\
COM12--C & 0.008 & COM25--C & -0.185 & COM38--C & 0.073 \\
COM13--C & 0.082 & COM26--C & -0.137 & & -- \\
\hline
\end{tabular}

The panel model of export path showing a negative correlation between enterprise scale, TFP and transaction costs associated with the level of exports. The larger the scale, the higher productivity, companies may consider other profitable decision path. Once transaction costs, the export companies will face higher trade and transport costs than the companies which choose other development path, thereby weakening export wishes. The share of R\&D investment, fixed costs, credit constraints and the relative GDP per capita showed a positive correlation associated with level of exports. Combined with the actual situation of China's auto industry, the exporters of auto companies get injected export tax rebate policy to encourage exports. And export enterprises relatively get more concessions in loans. Therefore, under the credit constraints, companies are more inclined to choose export. In addition, from the perspective of the relative GDP per capita can be drawn car companies prefer to export relatively developed countries.

\subsection{Internationalization Path Selection Model}

This study consider features of outsourcing, FDI, and export data in automobile industry separately, use WLS, principal components estimation and panel data to gain outsourcing modified regression model, FDI modified model and export path panel regression model. Mesh mentioned 3 international path models, then international path selection model is arose:

$$
\left\{\begin{array}{l}
\text { Out }^{*}{ }_{j}=-0.09-0.64 x_{(j, 1)}-0.36 x_{(j, 2)}+0.42 x_{(j, 3)} \\
-0.75 x_{(j, 4)}+0.91 x_{(j, 5)}+0.30 x_{(j, 6)}-0.50 x_{(j, 7)}+1.06 x_{(j, 8)} \\
F D I^{*}{ }_{j}=1.32+0.01 x_{(j, 1)}-1.14 x_{(j, 2)}+0.17 x_{(j, 3)} \\
-1.19 x_{(j, 4)}-0.12 x_{(j, 5)}+0.17 x_{(j, 6)}+0.20 x_{(j, 7)}-0.24 x_{(j, 8)} \\
E^{*}{ }^{*}{ }_{j}=C_{j}-0.17 x_{(j, 1)}-0.17 x_{(j, 2)}+0.02 x_{(j, 3)} \\
+0.18 x_{(j, 6)}+0.12 x_{(j, 7)}+0.42 x_{(j, 8)}-0.18 x_{(j, 9)}
\end{array}\right.
$$

Where: 
Out $^{*}{ }_{j}, F D I^{*}{ }_{j}$ and $\operatorname{Exp}_{j}{ }_{j} \longrightarrow$ The level of outsourcing, FDI, and export;

$x_{(j, k)} \longrightarrow$ Firm scale, productivity, R\&D, capital intensive, specific investment, fixed cost, credit constrict,

relative GDP per capita and trade cost in the $j$-th firm, where;

$C_{j}-$ Intercept in the $j$-th firm.

\section{Discussion}

Comparing 3 international path selection models, we could analyze strategies in terms of factors which could affect firms' international path and aims of firms, and give some suggestion for corporate development strategy.

On the one hand, from the point of view of influence factors of enterprise's path, a firm prefers to select FDI when its scale becomes larger, because FDI needs abundant capital, only if the firm's scale is big enough could it holds FDI. Capital intensity and specific investment have a negative function to FDI, it suggests considering high opportunity cost in FDI, the firm would choose export instead of FDI when it needs high up-front cost and fixed cost. So export is more flexible than FDI, when foreign market has a movement, it is more possible than FDI to change its direction of management, to carry out a more matched management strategy. What's more, the higher the relative GDP per capita is, the higher the level of outsourcing of the firm. Firms prefer to contract issue to developed country, it illustrates that most firms in Chinese automobile business choose technology contract, so technology in Chinese automobile industry needs to be improved. However, credit constraint could reduce the willing of outsourcing, and make it transfer to export and FDI. Because technology could be deemed to a way of import, contract issuing firms would face higher risk and costs, so it requires higher condition for borrowing, and further reduce firms' willing of borrowing. On the contrary, the level of export and FDI are positive to credit constraint, combined with Chinese policies to encourage exports, such as export-drawback policy and loan preferential policy, firms would face lower loan cost in export and FDI, so multinational corporations prefer to export and FDI when credit constraint is strong. At the same time, transfer costs would reduce firms' export return beyond all doubt.

On the other hand, in terms of corporation's international development goals, if corporation choose export, it needs to increase its R\&D share, in order to catch up with technological sophistication in world market. Meanwhile, corporation's benefits could be increased by making full use of export of preferential policies and reducing transfer costs. Corporation which prefer to FDI should consider fixed costs it should input, setting a firm abroad means firms need input abundant capital, and thus it should consider its scale. Only if it has a certain degree of scale, firm could have opportunity to provide capital and have ability to endure risk and to compete against local firms.

According to internationalization path selection model in automobile industry, we could analyze differences on corporations' international development strategies made by some conditions. And then, we could make some useful suggestion in firms' international goals, help them constitute practical strategy, finally improve its international competition.

Based on analyze in internationalization path selection model, we could make some suggestions for individual firm's international development. When a firm wants to choose a way of moving towards worlds, what conditions it should have, which unfavorable factors it should consider, the firm should combine relevant policies, adjust its business strategy, and achieve its sustainable development in world market.

What's more, it is easy to see that internationalization path selection model in this study is suitable for more than the automobile industry, it could be applied to every industry. What we should do is researching the industry's dynamic development and heterogeneity among firms, considering its features of developing, analyzing internal relation in every firm's financial index, selecting a suitable regression model, and then getting its internationalization path selection model, and amending the model, making it be matched to real features of developing in this industry.

\section{Conclusion}

Comparing with the analysis of corporations' international path based on traditional trade theory, this study fully considers the influence which microscopic factors make on decisions based on new-new trade theory, and then makes empirical research about international path selection using part of Chinese listed automobile enterprise. 
This study selects some microscopic factors such as productivity, capital intensive, specific investment, firm's scale, R\&D, fixed cost, international transfer cost and so on, selects macro factors such as credit constraint, GDP per capital and so on, and then makes these factors as independent variables, makes the level of outsourcing, FDI and export as a dependent variable separately, and frames three regression equations using WLS, principal components estimation and panel regression model, with a very good fitting effect.

Further more, according to these empirical studies, we get international path selection multiple model through integrating three international path regression equation. In this model, the study combines with Chinese automobile industry, uses micro factors and macro factors, analyses its differential influence on the level of each international path and its differential degree of decision on international path. Finally, this study provides specific suggestions for international path selection strategies about Chinese automobile industry, and generalizes this model.

\section{Acknowledgments}

Thanks Haijun Huang, Qing Su and Fanfeng Zeng for their personal assistance in manuscript preparation. We are also particularly grateful to Jinan University.

\section{References}

Amiri, A. S. F., Seidi, M., \& Riasi, A. (2012). Identifying the Barriers to Iran's Saffron Export by Using Porter's Diamond Model. International Journal of Marketing Studies, 4(5), 129-138. http://dx.doi.org/10.5539/ijms.v4n5p129

Antràs, P. (2003). Firms, Contracts, and Trade Structure. Quarterly Journal of Economics, 118(4), 1375-1418. http://dx.doi.org/10.3386/w9740

Antràs, P., \& Helpman, E. (2004). Global Sourcing. Journal of Political Economy, 112(3), 552-580. http://dx.doi.org/10.3386/w10082

Baldwin, R., \& Okubo, T. (2006a). Heterogeneous Firms, Agglomeration and Economic Geography: Spatial Selection and Sorting. Journal of Economic Geography, 6(3), 323-346. http://dx.doi.org/10.1093/jeg/lbi020

Bernard, A. B., \& Bradford, J. (1995). Exporters, Jobs, and Wages in US Manufacturing: 1976-1987. Brookings Papers on Economic Activity, Microeconomics, 67-119. http://dx.doi.org/10.2307/2534772

Bernard, A. B., \& Bradford, J. (1999b). Exporting and Productivity: Importance of Reallocation. NBER Working Paper No.7135. http://dx.doi.org/10.2139/ssrn.167569

Bingxian, Y., \& Lixin, W. (2007). The Study of The Competitiveness of Automobile Industrial Cluster In China Under The Background of Globalization. Science \& Technology Progress and Policy, 24(9).

Chunding, L. (n. d.). Whether Chinese export enterprise has "Productivity Paradox" —_Baxed on The Test of Chinese 3 million of manufacturing enterprises data. The Report of Institute of World Economics and Politics Chinese Academy of Social Sciences.

Douglas, F. P., Nathan, Y. S., \& David, A. W. (2012). Internal Audit Outsourcing and the Risk of Misleading or Fraudulent Financial Reporting: Did Sarbanes-Oxley Get It Wrong. Contemporary Accounting Research, 29(4), 1109-1136. http://dx.doi.org/10.1111/j.1911-3846.2012.01141.x

Guanfeng, L., Enzhong, Y., Jilai, Y., \& Xiankun, G. (2013). The Current Situation and The Development Trend In Chinese Automobile Industry. Zhengzhou: The Ninth Session of The Automobile Industry Technical Seminar In Henan Province, 2013.

Jingli, L. (2013). Study of FDI in Chinese Automobile Industry. Beijing: Capital University of Economics and Business, 2013.

Melitz, M. (2003). The Impact of Trade on Intra-Industry Reallocations and Aggregate Industry Productivity. Econometrica, 71(6), 1695-1725. http://dx.doi.org/10.1111/1468-0262.00467

Mingyan, Y. (2010). Organization Choices of Firm, Export and Outsourcing. Tianjin: Nankai University, 2010.

Nocke, V., \& Yeaple, S. (2007). Cross-border Mergers and Acquisitions vs. Greenfield Foreign Direct Investment: The Role of Firm Heterogeneity. Journal of International Economics, 72. http://dx.doi.org/10.1016/j.jinteco.2006.09.003

Nocke, V., \& Yeaple, S. (2008). An Assignment Theory of Foreign Direct Investment. Review of Economic Studies, 75(2), 529-557. http://dx.doi.org/10.1111/j.1467-937X.2008.00480.x

Pengfei, C. (2002). The Macro-analysis to the Automobile Market Demand of the World and Sales Strategy in 
Chinese Auto Industry.

Riasi, A. (2015a). Barriers to international supply chain management in Iranian flower industry. Management Science Letters, 5(4), 363-368. http://dx.doi.org/10.5267/j.msl.2015.2.005

Riasi, A. (2015b). Competitive Advantages of Shadow Banking Industry: An Analysis Using Porter Diamond Model. Business Management and Strategy, 6(2), 15-27. http://dx.doi.org/10.5296/bms.v6i2.8334

Riasi, A., \& Amiri, A. S. F. (2013). Effects of a Hypothetical Iranian Accession to the World Trade Organization on Iran's Flower Industry. Consilience. The Journal of Sustainable Development, 10(1), 99-110. http://dx.doi.org/10.7916/D8HQ3ZK8

Riasi, A., \& Pourmiri, S. (2015). Effects of online marketing on Iranian ecotourism industry: Economic, sociological, and cultural aspects. Management Science Letters, 5(10), 915-926. http://dx.doi.org/10.5267/j.msl.2015.8.005

Riasi, A., \& Pourmiri, S. (2016). Examples of Unsustainable Tourism in Middle East. Environmental Management and Sustainable Development, 5(1), 69-85. http://dx.doi.org/10.5296/emsd.v5i1.8705

Xin-zhong, B., \& Xiao, M. (2010). Approach for Stock Investment Decisions Based on Rough Set Theory. Journal of Systems \& Management, 19(5), 526-533.

Xiujun, G. (2013). The Current Situation And The Development Trend of FDI In Chinese Automobile Industry. The Foreign Trade and Economic Cooperation, (6), 43-47. http://dx.doi.org/10.3969/j.issn.2095-3283.2013.06.015

Zhang, X. (2012). Research on Relationship between Economic Growth and Energy Consumption in Liaoning-based on The Panel Date. Shenyang: Northeastern University, 2012.

Zinai, L., \& Wenqing, P. (2004). Econometrics (pp. 107-155).

\section{Copyrights}

Copyright for this article is retained by the author(s), with first publication rights granted to the journal.

This is an open-access article distributed under the terms and conditions of the Creative Commons Attribution license (http://creativecommons.org/licenses/by/3.0/). 